\title{
SZACUNKI MNOŻNIKÓW FISKALNEGO, INWESTYCYJNEGO I EKSPORTOWEGO W GOSPODARCE POLSKI W LATACH 2005-2020**
}

\section{WPROWADZENIE}

Zagadnienie mnożników fiskalnego, inwestycyjnego i eksportowego jest jednym z ważniejszych we współczesnej ekonomii, zarówno ze względów rozważań teoretycznych, jak i z punktu widzenia praktyki polityki gospodarczej. Ukazują one poziom reakcji wartości PKB na zmiany wydatków autonomicznych. Mnożniki te ujawniają zarówno zasilenia, jak i wycieki łącznego popytu w gospodarce. Tym samym autor podjął próbę zbadania tego zagadnienia w polskiej gospodarce. Główna jednak przyczyna podjęcia tego problemu stało się pewne stwierdzenie, które pojawia się dość często w literaturze przedmiotu. Mowa jest o metodycznej trudności obliczania poziomów importochłonności ${ }^{1}$. Te zaś są bezwzględnie konieczne do wyliczenia mnożników wydatków autonomicznych zgodnie z zasadami łącznego popytu.

$\mathrm{W}$ tym kontekście autor podją próbę zrewidowania tradycyjnego podejścia do kalkulacji mnożników fiskalnego, inwestycyjnego i eksportowego. Zatem głównym celem artykułu jest próba rozwiązania dylematu z obliczaniem przedmiotowych tu mnożników. Autor zaproponował odmienne podejście do podziału całkowitego importu. Za jego podstawę przyjęto podstawowe klasy towarów w Systemie Rachunków Narodowych w odniesieniu do broad economic categories (BEC). Umożliwiło to obliczenie poziomów importochłonności w krótkim okresie na podstawie dostępnych danych statystycznych.

Wykorzystując opisaną metodę, autor dokonał szczegółowych obliczeń wszystkich wskaźników wymaganych teorią efektywnego popytu. Na ich pod-

" Arkadiusz J. Derkacz, Społeczna Akademia Nauk w Warszawie oraz Narodowy Bank Polski, derakacz@san.edu.pl, https://orcid.org/0000-0003-1363-9551.

** Artykuł reprezentuje wyłącznie poglądy autora, a nie oficjalne stanowisko NBP.

1 Przybyliński (2012); Czyżewski, Kryszak (2016); Łaski, Osiatyński, Zięba (2010c), (2012). 
stawie oszacował ostatecznie wartości mnożników fiskalnego, inwestycyjnego i eksportowego w krótkim okresie. W tym celu wykorzystano dane statystyczne Zintegrowanej Bazy Danych Ekonomicznych Narodowego Banku Polskiego (ZBDE NBP). Do analizy przyjęto okres od I kwartału 2005 do I kwartału 2020 r. Prezentowany sposób podziału importu umożliwił autorowi oszacowanie wszystkich mnożników oraz wymaganych wskaźników w układzie kwartalnym. To pozwoliło na podjęcie próby krótkoterminowej (kwartalnej) analizy zmian wartości mnożników fiskalnego, inwestycyjnego i eksportowego w polskiej gospodarce w analizowanym okresie czasu.

W pierwszej części artykułu przedstawiono podstawy ekonomiczne badań mnożników fiskalnego, inwestycyjnego i eksportowego. Opisany został także sposób obliczania krótkoterminowych poziomów importochłonności. W drugiej części przedstawiono zebrane dane oraz wykonano odpowiednie obliczenia, które umożliwiają oszacowanie mnożników wydatków autonomicznych dla polskiej gospodarki. Na końcu tej sekcji oszacowano mnożniki fiskalny, inwestycyjny i eksportowy. W ostatniej części artykułu zaprezentowano najważniejsze konkluzje. W tym celu pokazano zmiany mnożników autonomicznych wydatków. Ponadto zastosowana przez autora metoda podziału importu według głównych kategorii ekonomicznych (BEC) pozwala na krótkookresowe (kwartalne) analizy zmian mnożników wydatków autonomicznych. Tym samym metoda ta może umożliwić dalsze badania zasileń i wycieków łącznego popytu, które są ostatecznymi determinantami zmian PKB.

\section{FUNDAMENT EKONOMICZNY}

Autor, realizując cel swoich badań, bazuje na metodzie szacowania mnożników, która jest stosowana $\mathrm{w}$ podobnych publikacjach ${ }^{2}$. Niestety, choć zagadnienie wydaje się bardzo istotne, liczba poświęconych mu publikacji jest bardzo mała. Głównym fundamentem prowadzonych badań jest teoria efektywnego popytu. Jedną z jej podstaw jest założenie, że w gospodarce mamy do czynienia z nierozłącznym stanem niestabilności ${ }^{3}$. Jest on w głównej mierze uzależniony od decyzji inwestycyjnych ${ }^{4}$. Równie ważne jest także zagadnienie niepełnego wykorzystania środków produkcyjnych $\mathrm{w}$ gospodarkach kapitalistycznych. W tym kontekście zmiany produktu krajowego brutto pozostaja determinowane poprzez wielkości wydatków autonomicznych. Sa nimi wydatki na inwestycje prywatne, wydatki publiczne oraz eksport. Z kolei stosunek zmiany wielkości PKB do zmian poszczególnych wydatków autonomicznych nazywa się mnożnikami tychże wydatków. Mamy więc do czynienia z mnożnikiem wydatków publicznych (inaczej: mnożnik fiskalny), mnożnikiem inwestycyjnym i mnożnikiem eksportowym. Odnosząc to do zagadnienia łącznego

\footnotetext{
2 Łaski, Osiatyński, Zięba (2010b); Palley (2009): 311-322.

${ }^{3}$ Akerlof, Yellen (1987): 137-142.

4 Łaski (2019): 149-161.
} 
popytu, można powiedzieć, że wydatki autonomiczne są czynnikami zasilającymi. Oznacza to, że wzrost wydatków autonomicznych powoduje wzrost wartości produktu krajowego brutto. Z drugiej strony mamy do czynienia $\mathrm{z}$ tzw. wyciekami łącznego popytu ${ }^{5}$. W tym kontekście pojawiają się podatki, import oraz oszczędności prywatne. Oznacza to, że wzrost tych wielkości w gospodarce spowalnia zmiany PKB.

Mnożniki wydatków autonomicznych pokazuja, w jakim stopniu PKB reaguje na zmianę poszczególnych wydatków. Okazuje się, że zmiana PKB nie jest zawsze równa zmianie wartości wydatków autonomicznych. W klasycznym ujęciu ta nieproporcjonalność jest tłumaczona głównie przez krańcową skłonność do konsumpcji. Ta z kolei jest determinowana skłonnością do oszczędności prywatnych brutto oraz przeciętną stopą oprocentowania. Zostanie to opisane $\mathrm{w}$ dalszej części tego punktu. Przyczyny te sa ukryte w mnożnikach w postawni tzw. wycieków łącznego popytu. Badanie zmian wartości mnożników fiskalnego, inwestycyjnego i eksportowego ma zatem istotne znaczenie dla prognozowania polityki gospodarczej. Stabilny poziom tych mnożników w długim okresie powoduje stabilizację otoczenia polityki gospodarczej. Niepewność związana ze zmiennością mnożników wydatków autonomicznych może być źródłem ryzyka gospodarczego ${ }^{6}$. Problem niepewności wartości mnożników fiskalnego, inwestycyjnego i eksportowego ma znaczenie zarówno dla sektora przedsiębiorstw ${ }^{7}$, jak i dla sektora publicznego ${ }^{8}$. Niepewność tę należy jednak rozumieć w taki sposób, że duża, także krótkookresowa, ich zmienność będzie powodowała różną reakcję PKB na zmiany wydatków autonomicznych. Takie podejście do zagadnienia niepewności w gospodarce jest jedną z przyczyn, dla których autor podją próbę przedefiniowania sposobu obliczania wartości mnożników fiskalnego, inwestycyjnego i eksportowego. Ma to umożliwić badanie zmienności tych mnożników w krótkim okresie.

Oprócz głównego fundamentu merytorycznego autor przyjmuje także podstawowe założenia modelu keynesowskiego. Są nimi założenia, że (1) w gospodarce występuje niepełne wykorzystanie czynników wytwórczych oraz (2) istnieją nieznaczne zmiany w podziale dochodu narodowego pomiędzy płacami i marża zysku brutto, oraz (4) realizowana jest akomodacyjna polityka podaży pieniądza. W tym kontekście należy stwierdzić, że produkt krajowy brutto jest sumą prywatnej konsumpcji $(C P)$, inwestycji prywatnych (IP), wydatków publicznych $(G)$, eksportu $(X)$ pomniejszoną o wartość importu $(M)^{9}$. Można to przedstawić w równaniu:

$$
Y=C P+I P+G+X-M .
$$

\footnotetext{
${ }^{5}$ Łaski, Osiatyński, Zięba (2012).

${ }^{6}$ Andrade, Mattos, Lima (2018): 118.

${ }^{7}$ Ko et al. (2018): 98.

${ }^{8}$ Fischer (2011): 751-762; Schultz (2002): 487-506.

${ }^{9}$ Łaski (2019): 1-5.
} 
Przyjmując, że suma podatków netto (TN) stanowi różnicę pomiędzy wszelkimi dochodami podatkowymi i obciążeniami sektora przedsiębiorstw oraz gospodarstw domowych a wszystkimi transferami sektora publicznego, uzyskujemy wielkość dochodu do dyspozycji sektora prywatnego $(Y D=Y-T N)$. Jednocześnie wielkość $T N$ będzie stanowiła dochód do dyspozycji sektora publicznego. Tym samym mamy zależność $Y=Y D+T N$. W tym miejscu należy wprowadzić wartość oszczędności brutto sektora prywatnego $(S P)$. Stanowi ona różnicę pomiędzy dochodem do dyspozycji sektora prywatnego a konsumpcją prywatna. Na tej podstawie możemy zapisać, że $C P=Y-T N-S P$ oraz $Y=C P+T N+S P$.

W dalszej kolejności należy wprowadzić pojęcie przeciętnej stopy oszczędności prywatnych $s p={ }^{S P} /{ }_{Y}$ oraz przeciętnej stopy opodatkowania netto $t n={ }^{T N} /{ }_{Y}^{10}$. $\mathrm{Na}$ tej podstawie otrzymujemy równanie określające poziom konsumpcji prywatnej $C P=(1-t n-s p) Y$. Przyjmując, że skłonność do konsumpcji prywatnej jest określona wzorem $c p=(1-t n-s p)$, otrzymujemy następującą zależność:

$$
C P=c p Y \text {. }
$$

Wprowadźmy w tym miejscu pojęcie absorpcji krajowej (A). Jest to suma wartości inwestycji prywatnych $(I P)$, wydatków publicznych wraz z inwestycjami publicznymi $(G)$ oraz konsumpcji prywatnej $(C P)$. Można to zapisać w równaniu:

$$
A=I P+G+C P
$$

Jeżeli absorpcję krajową powiększymy o wartość eksportu, uzyskujemy wartość produkcji finalnej $(F G=A+X)$. Na wykresie 1 przedstawiono względne zmiany kwartał do kwartału roku poprzedniego (QoQ_PY) wartości składowych produkcji finalnej dla Polski w latach 2005-2020. Dane przedstawiono w układzie kwartalnym.

\section{Wykres 1}

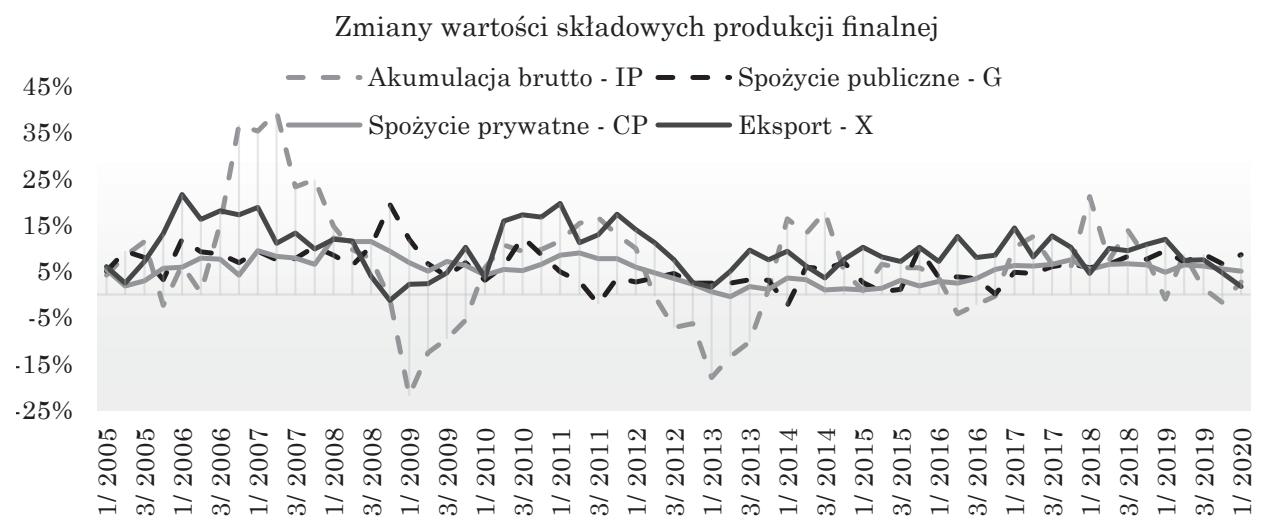

Źródło: opracowanie własne na podstawie danych ZBDE NBP.

${ }^{10}$ Łaski (2019): 36 i 59. 
W tradycyjnym podejściu na tej podstawie dokonuje się dekompozycji importu. Wyznacza się także wskaźniki importochłonności produkcji finalnej, absorpcji krajowej i eksportu ${ }^{11}$. W tym celu import dzieli się według równania $M=M_{A}+M_{X}$. Mamy więc import absorpcji krajowej $\left(M_{A}\right)$ oraz import wykorzystywany na wytworzenie dóbr eksportowanych $\left(M_{X}\right)$. Na tej podstawie określa się współczynniki importochłonności. Importochłonność absorpcji krajowej określa równanie $m_{A}=M_{A} /_{A}$. Natomiast importochłonność eksportu określa wzór $m_{X}=M_{X} /_{X}$. Na tej podstawie określa się wartość importu w postaci wzoru:

$$
M=\left(m_{A} c p Y+m_{A} I P+m A G\right)+m_{X} X
$$

Na podstawie wzoru (1), (2) i (4) po odpowiednich przekształceniach otrzymujemy:

$$
Y=\frac{\left(1-m_{A}\right) G+\left(1-m_{A}\right) I P+\left(1-m_{X}\right) X}{1-c p\left(1-m_{A}\right)}
$$

W tradycyjnym podejściu do zagadnienia mnożnika wydatków autonomicznych import jest jeszcze bardziej dezagregowany. Import dóbr jest przypisywany do każdej części składowej produkcji finalnej. Mamy więc importochłonność konsumpcji prywatnej $\left(m_{C P}=M_{C P} /_{C P}\right)$, wydatków publicznych $\left(m_{G}=M_{G} /{ }_{G}\right)$, inwestycji prywatnych $\left(m_{I P}=M_{I P} /_{I P}\right)$ oraz eksportu $\left(m_{X}=M_{X} /_{X}\right)$. Na tej podstawie przekształcono równanie (4), które otrzymało następująca postać:

$$
M=m_{C P} c p Y+m_{I P} I P+m_{G} G+m_{X} X .
$$

Wykorzystując równania (1) i (4.1), zweryfikowano także wzór (5). W tym momencie przyjmuje on postać:

$$
Y=\frac{\left(1-m_{G}\right) G+\left(1-m_{I P}\right) I P+\left(1-m_{X}\right) X}{1-c p\left(1-m_{C P}\right)} .
$$

To równanie jest podstawą do badań zmienności mnożników wydatków autonomicznych. Równanie to pokazuje, w jaki sposób zmienne autonomiczne determinują wartość PKB. Z jednej strony mamy zmienne $G, I P$ oraz $X$, które zasilają łączny popyt, z drugiej - mamy współczynnik skłonności do konsumpcji prywatnej ( $c p)$ oraz poszczególne wskaźniki importochłonności. Należy zauważyć tu pewne zależności. Wzrost poszczególnych współczynników importochłonności będzie powodował spadek wartości $Y$. Z kolei wzrost współczynnika cp przyczyni się do wzrostu wartości $Y$. Należy tu przypomnieć zależność $c p=1-t n-s p$, która pojawiła się $\mathrm{w}$ omawianiu wzoru (2). Wynika z tego, iż wzrost współczynnika cp jest możliwy w sytuacji spadku wartości współczynnika skłonności do oszczędności prywatnych brutto i/lub przeciętnej stopy pro-

11 Łaski, Osiatyński, Zięba (2010a): 805-830. 
centowej. Zakładając stały poziom tn można powiedzieć, że współczynnik cp jest uzależniony od poziomu współczynnika sp. Te wartości ujawniają nam tzw. wycieki łącznego popytu, którymi są import oraz oszczędności brutto sektora prywatnego. Można zatem powiedzieć, że autonomiczne wydatki, przy określonych wyciekach popytu, wyznaczają wartość PKB. W tym miejscu ujawnia się istota mnożników wydatków autonomicznych ${ }^{12}$. Określają one reakcję PKB na zmiany poszczególnych wydatków autonomicznych.

W tym momencie należy zastanowić się nad kluczową kwestią tego artykułu. W publikacjach opisujących mnożniki wydatków fiskalnych, inwestycyjnych i eksportowych pojawia się informacja o pewnej trudności metodycznej. Dotyczy ona wyliczania wskaźnika importochłonności absorpcji krajowej ${ }^{13}$. W publikacjach tych bazuje się na bilansie przepływów międzygałęziowych ${ }^{14}$. W Polsce jest on publikowany co 5 lat. W pozostałych krajach europejskich częstotliwość publikacji bilansu przepływów międzygałęziowych także jest niezadowalajacca. W danych dostępnych w bazie Eurostat po 2015 r. mamy dostępnych tylko 10 takich bilansów ${ }^{15}$. Taka sytuacja sprawia, że badanie zmienności mnożników fiskalnego, inwestycyjnego i eksportowego staje się mało przydatne, zarówno dla badań ekonomicznych, jak i dla uprawiania polityki gospodarczej. Autor proponuje inne podejście do kalkulacji wskaźników importochłonności. Bazuje on na podziale importu według podstawowych klas towarów w Systemie Rachunków Narodowych według broad economic categories (BEC). Import towarów jest tu dzielony na import dóbr zaopatrzeniowych $\left(M_{D Z}\right)$, dóbr inwestycyjnych $\left(M_{D I}\right)$ oraz dóbr/towarów konsumpcyjnych $\left(M_{D K}\right)$. Całkowity import dóbr można zatem oznaczyć w następujący sposób:

$$
M=M_{D Z}+M_{D I}+M_{D K}
$$

Tak podzielony import można przyporządkować do głównych czynników zasilających absorpcję krajowa (IP, $C P, G)$ oraz eksport (X) (zob. schemat 1). Autor przyjmuje następujące założenia. Import dóbr konsumpcyjnych można w całości przyporządkować do konsumpcji prywatnej $(C P)$. Import dóbr inwestycyjnych jest w całości absorbowany przez akumulację brutto (IP). Jednak akumulacja brutto absorbuje nie tylko importowane dobra inwestycyjne. Wykorzystuje także importowane dobra zaopatrzeniowe $\left(M_{D Z}\right)$. Z kolei importowane półprodukty są absorbowane w gospodarce przez akumulację brutto, a także przez wydatki publiczne oraz eksport. W tym kontekście autor wprowadził odpowiedni podział importu dóbr zaopatrzeniowych. Dobra zaopatrzeniowe

12 Łaski (2019): 99-103.

13 Łaski, Osiatyński, Zięba (2010c): 17.

14 Rueda-Cantuche et al. (2017); Statistics Poland, Input-output table at basic prices in 2015. Statistical information, 2019.

15 Eurostat po 2015 r. opublikował bilans przepływów międzygałęziowych w cenach bazowych dla następujących państw: w 2016 dla Niemiec, Hiszpanii, Francji, Włoch, Cypru, Luksemburga i Austrii; 2017 - Luksemburga i Portugalii; w 2018 ukazał się ten bilans tylko dla Luksemburga. Informacje na podstawie „Symmetric input-output table at basic prices (product by product)”, bazy danych Eurostat (dostęp: lipiec 2020). 
moga być absorbowane przez inwestycje prywatne, produkcję przeznaczona na eksport oraz wydatki publiczne, które należy rozumieć jako całkowite wydatki publiczne włącznie z inwestycjami publicznymi. Z tego powodu konieczne jest wprowadzenie pewnych współczynników, które w odpowiedni sposób podzielą całkowity import dóbr zaopatrzeniowych.

\section{Schemat 1}

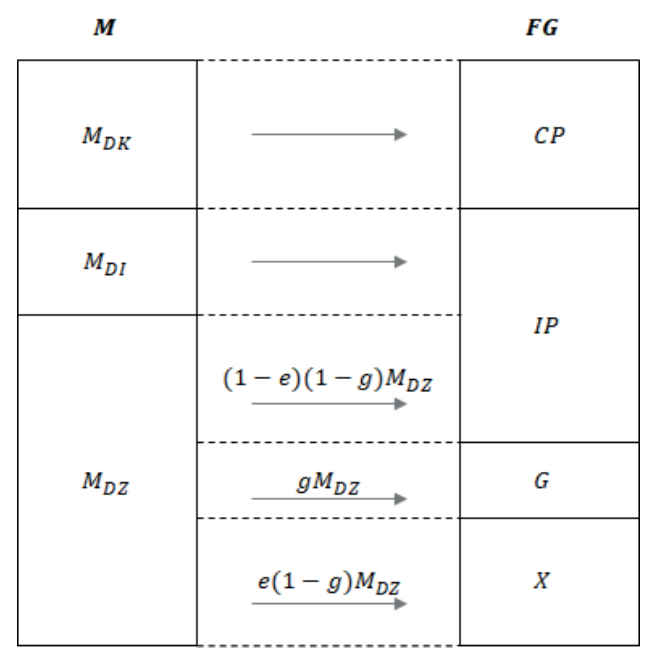

Dekompozycja importu według BEC

Źródło: opracowanie własne.

Wydatki publiczne należy rozumieć jako wielkość spożycia w sektorze publicznym. Tym sposobem część importu dóbr zaopatrzeniowych jest absorbowana właśnie na tego rodzaju wydatki. Autor proponuje, aby wielkość tej absorpcji obliczyć na podstawie współczynnika g. Oznaczać on będzie udział wydatków publicznych w wartości dodanej brutto w danym okresie. Warto w tym miejscu stwierdzić, zgodnie z sugestią Jana Toporowskiego, że taki podział importu dóbr zaopatrzeniowych jest użyteczny w krótkim terminie. Długoterminowe prognozowanie na podstawie takiej dekompozycji importu może dać błędne wyniki. Wynika to z tego, że struktura gospodarki krajowej może ulegać zmianie w długim okresie. Dlatego autor w swoich obliczeniach używa krótkiego okresu (kwartał), a współczynnik $g$ jest kalkulowany dla każdego z analizowanych okresów. W planach badawczych autora jest porównanie wartości poszczególnych wskaźników importochłonności w okresach kwartalnych i rocznych. Na wykresie 2 przedstawiono ten współczynnik dla Polski w okresie od 2015 do I kwartału 2020 r. Wskaźnik zmienności, liczony jako stosunek odchylenia standardowego do średniej wartości tego współczynnika ${ }^{16}$, jest bardzo niski. W okresie od 2005

16 Abdi (2010): 169-171. 
do I kwartału 2020 r. współczynnik zmienności wyniósł 4,49\%. Na tej podstawie można więc stwierdzić, że wydatki publiczne absorbują import dóbr zaopatrzeniowych o wartości $g M_{D Z}$. Przy czym absorpcja ta jest dość stabilna w analizowanym okresie. Pozostała część importu dóbr zaopatrzeniowych o wartości $(1-g)$ $M_{D Z}$ jest absorbowana przez produkcję finalną sektora przedsiębiorstw. Wartość tę będziemy określali jako $p M_{D Z}$. Współczynnik $p$ oznacza zatem tę część importu dóbr zaopatrzeniowych, która jest absorbowana przez przedsiębiorstwa ( $p=$ $1-g$ ). Tym samym import dóbr zaopatrzeniowych rozdzielony został pomiędzy sektor prywatny i publiczny.

Wykres 2

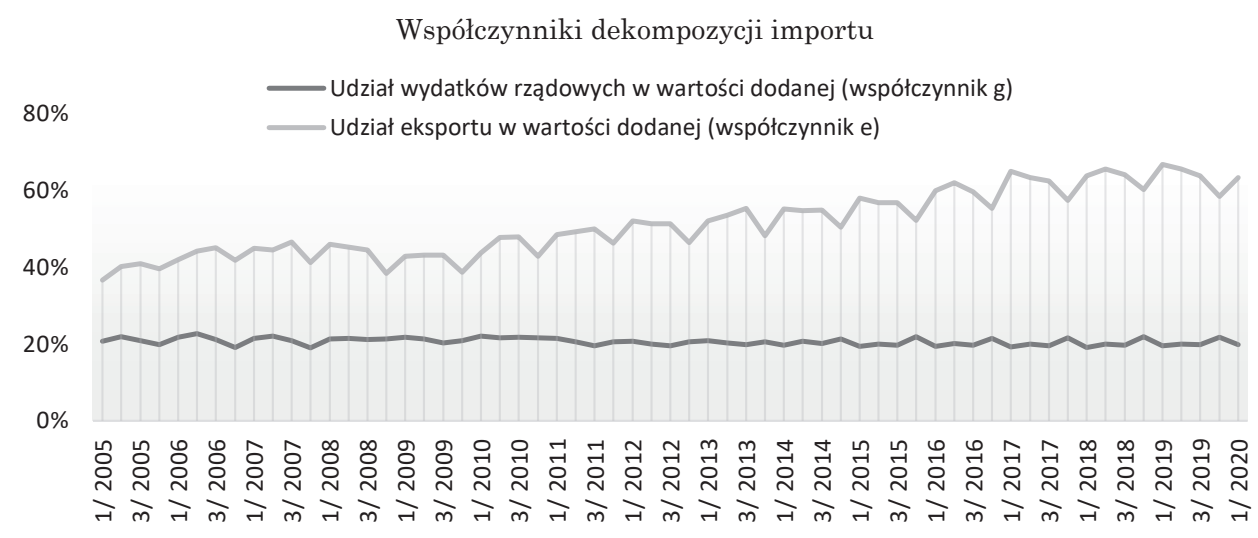

Źródło: opracowanie własne na podstawie ZBDE NBP.

Pozostaje jeszcze podział części importu dóbr zaopatrzeniowych $\left(p M_{D Z}\right)$ na absorpcję krajową i na eksport. W tym celu autor proponuje współczynnik $e$. Współczynnik ten oznacza udział eksportu w wartości dodanej brutto w danym okresie. Wartość tego współczynnika należy także analizować w krótkim okresie, podobnie jak współczynnik g. Także i w tym przypadku autor do obliczenia współczynnika $e$ wykorzystuje dane kwartalne (zob. wykres 3). W okresie od 2015 do I kwartału 2020 r. (układ kwartalny) współczynnik zmienności dla Polski wyniósł 16,3\%. Mamy więc tu do czynienia z dość dużą zmiennością wartości współczynnika $e$. Ponadto wykazuje on niemalże nieprzerwany trend wzrostowy w tym okresie. Od 2005 r. jego wartość wzrosła o 72,9\%. Wykorzystując ten współczynnik, można wyliczyć tę część importu dóbr zaopatrzeniowych, która zostanie wykorzystana na wytworzenie dóbr przeznaczonych na eksport. Wartość tę można określić jako e $(1-g) M_{D Z}$ lub ep $M_{D Z}$. Pozostała część importowanych dóbr zaopatrzeniowych jest wykorzystywana na absorpcję krajowa. Jej wartość można przedstawić jako $(1-e) p M_{D Z}$. Można tu wprowadzić współczynnik $a=1-e$, który będzie określał udział tej części importu dóbr zaopatrzeniowych absorbowanych na potrzeby akumulacji brutto $\left(a p M_{D Z}\right)$. 
Wykres 3

Dekompozycja importu i produkcja finalna (w mld PLN)

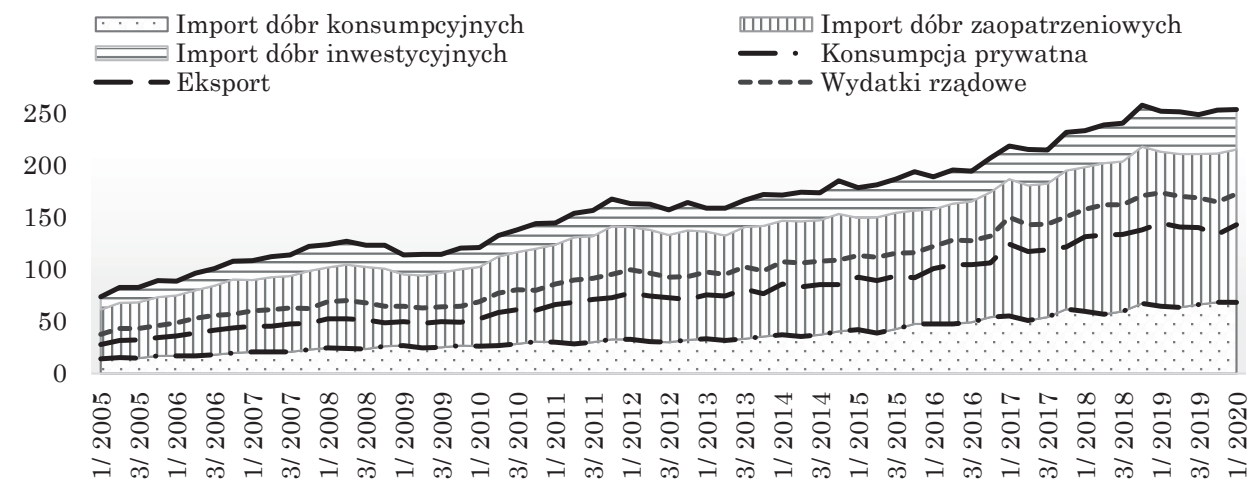

Źródło: opracowanie własne na podstawie ZBDE NBP.

Tym sposobem dekompozycję całkowitego importu można zapisać równaniem:

$$
M=M_{D K}+\left(M_{D I}+a p M_{D Z}\right)+g M_{D Z}+e p M_{X}
$$

Zostało to także zobrazowane na wykresie 3. Przedstawia on dwie grupy skumulowanych wartości dla Polski w okresie od 2005 do I kwartału 2020 r. Skumulowany wykres warstwowy ukazuje dekompozycję importu według kategorii ekonomicznych BEC. Widać tam podział całkowitego importu na import dóbr zaopatrzeniowych, dóbr inwestycyjnych oraz dóbr konsumpcyjnych. Druga część wykresu 3 to skumulowany liniowy wykres przedstawiajacy podział importu na poszczególne elementy produkcji finalnej. Innymi słowy, wykres 3 przedstawia rzeczywistą sytuację polskiej gospodarki, która w sposób teoretyczny została przedstawiona na schemacie 1.

Z powyższych zapisów arytmetycznych wynika, że importochłonność absorpcji krajowej jest uzależniona od importu, który można zapisać w postaci $M_{A}=M_{D K}+\left(M_{D I}+a p M_{D Z}\right)+g M_{D Z}$. Importochłonność produkcji finalnej natomiast jest powiększona dodatkowo o wartość importu ep $M_{X}$, który jest przeznaczony na wytworzenie dóbr eksportowanych. Na tej podstawie można określić współczynniki importochłonności dla poszczególnych wydatków autonomicznych.

$$
m_{C P}=\frac{M_{D K}}{C P} ; m_{G}=\frac{g M_{D Z}}{G} ; m_{I P}=\frac{M_{D I}+a p M_{D Z}}{I P} ; m_{X}=\frac{e p M_{D Z}}{X}
$$

Tak definiowane składowe importu w dalszym ciagu pozostaja przybliżona wartością szacunkowa. Wydaje się jednak, że takie rozwiązanie może być wartościowe dla krótkoterminowej analizy importochłonności oraz mnożników fiskalnego, inwestycyjnego i eksportowego. Wykorzystanie takiej metody dekompozycji importu daje przede wszystkim możliwość badania 
zmienności mnożników fiskalnego, inwestycyjnego i eksportowego w okresach krótszych, niż jest to możliwe przy wykorzystaniu bilansu przepływów międzygałęziowych.

Zgodnie z równaniem (5.1) możemy teraz wydzielić mnożnik fiskalny $\left(k_{1}\right)$, inwestycyjny $\left(k_{1}\right)$ i eksportowy $\left(k_{3}\right)$. Przedstawiają to poniższe równania:

$$
k_{1}=\frac{\left(1-m_{G}\right)}{1-c p\left(1-m_{C P}\right)} ; k_{2}=\frac{\left(1-m_{I P}\right)}{1-c p\left(1-m_{C P}\right)} ; k_{3}=\frac{\left(1-m_{X}\right)}{1-c p\left(1-m_{C P}\right)} .
$$

Na tej podstawie otrzymujemy skróconą postać równania (5.1):

$$
Y=k_{1} G+k_{2} I P+k_{3} X
$$

Wartość $Y$ jest więc całkowicie uzależniony od wartości autonomicznych wydatków oraz od współczynników $k$.

W tradycyjnym ujęciu mnożniki fiskalny, inwestycyjny i eksportowy określaja, o ile zmienia się wartość PKB przy zmianie poszczególnych wydatków autonomicznych. Wykorzystując zaproponowaną metodę dekompozycji importu, zbadano zmiany wartości importochłonności. Przeanalizowano także wartości poszczególnych mnożników w okresach kwartalnych. Dlatego równanie (5.1) przyjmuje następująca postać ${ }^{17}$ :

$$
\Delta Y=\frac{\left(1-m_{G}\right) \Delta G+\left(1-m_{I P}\right) \Delta I P+\left(1-m_{X}\right) \Delta X}{1-c p\left(1-m_{C P}\right)} .
$$

Równanie to jest fundamentem dalszych obliczeń. Mają one na celu ukazanie reakcji zmiany $\mathrm{PKB}$ na zmiany wydatków autonomicznych przy danych mnożnikach fiskalnym, inwestycyjnym i eksportowy w gospodarce polskiej.

\section{SZACUNKI MNOŻNIKÓW WYDATKÓW AUTONOMICZNYCH}

W tym rozdziale autor obliczy wartości poszczególnych wskaźników, które określają mnożniki fiskalny, inwestycyjny i eksportowy. W tym celu wykorzystano dane dostępne w ZBDE NBP. W badaniach wykorzystałem następujace zestawienia danych: (1) produkt krajowy brutto (PKB) w cenach bieżących, (2) wartość dodana brutto w cenach bieżących, (3) akumulacja brutto w cenach bieżących, (4) spożycie prywatne (spożycie indywidualne w sektorze gospodarstw domowych oraz spożycie w sektorze instytucji niekomercyjnych) w cenach bieżących, (5) spożycie publiczne w sektorze instytucji rządowych i samorządowych w cenach bieżących, (6) eksport oraz import dóbr i usług

17 Łaski, Osiatyński, Zięba (2010a): 810. 
w cenach bieżących, (7) podatki od produktów pomniejszone o subsydia od produktów w cenach bieżących oraz (8) oszczędności brutto w sektorze gospodarstw domowych w cenach bieżących. W celu przedstawienia potencjalnych zmian mnożników przyjęto do analizy okres od 2015 do I kwartału 2020 r. Wykorzystano dane w układzie kwartalnym.

W pierwszej kolejności obliczono współczynnik skłonności do konsumpcji prywatnej $(c p)$. Według wzoru współczynnik ten jest stosunkiem konsumpcji prywatnej do wartości produktu krajowego brutto $(c p=C P / Y)$. Współczynnik wyliczono na podstawie wartości spożycia prywatnego i produktu krajowego brutto w cenach bieżących. Skalkulowano także współczynnik skłonności do oszczędności prywatnych $(s p)$. Współczynnik ten jest stosunkiem oszczędności prywatnych do wartości PKB $(s p=S P / Y)$. W tym celu wykorzystano dane oszczędności brutto w sektorze gospodarstw domowych w cenach bieżących. Obliczono także przeciętną stopę opodatkowania (tn). Jest ona stosunkiem sumy podatków netto do produktu krajowego brutto $(t n=T N / Y)$. W kalkulacji tego współczynnika wykorzystano wartości podatków od produktów pomniejszone o subsydia od produktów w cenach bieżących. Wyniki tych obliczeń przedstawiono na wykresie 4.

Wykres 4

Współczynniki $c p, s p$ i $t n$

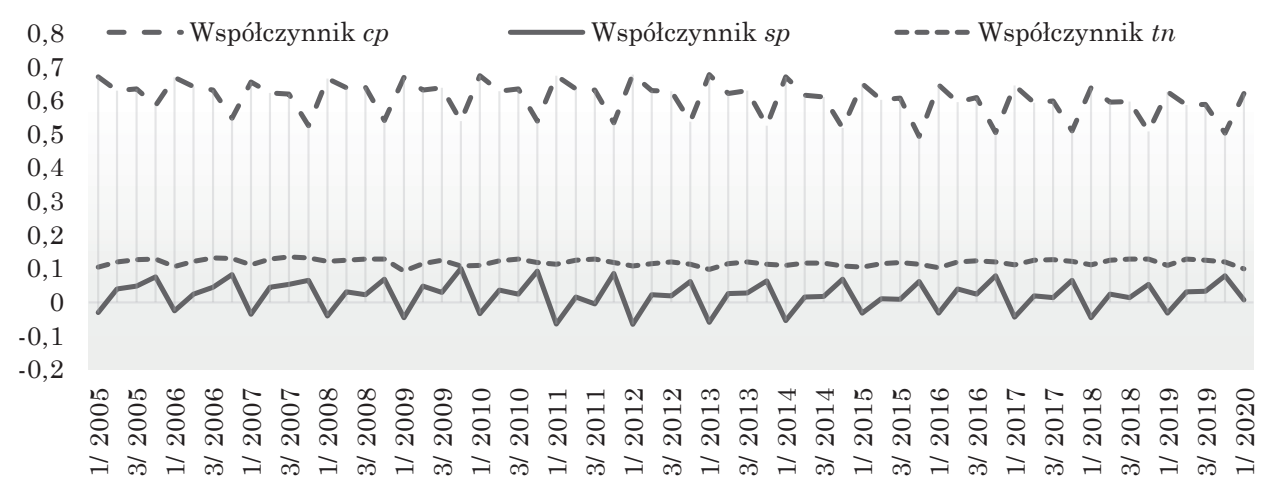

Źródło: opracowanie własne na podstawie ZBDE NBP.

Można teraz przejść do kalkulacji wskaźników importochłonności. W tym celu zostanie wykorzystana metoda, która opisano wcześniej (zob. wzór 6.1 i 7) W pierwszej kolejności można obliczyć współczynnik importochłonności konsumpcji prywatnej $\left(m_{C P}\right)$. Został on określony jako stosunek importu dóbr konsumpcyjnych do konsumpcji prywatnej $\left(m_{C P}={ }^{M_{D K}} / C P\right)$. Do wyliczenia tego wskaźnika wykorzystano wartości spożycia prywatnego w cenach bieżących oraz wartość importu dóbr konsumpcyjnych. 
Następnie obliczono współczynnik importochłonności wydatków publicznych $\left(m_{G}\right)$. Jest on zdefiniowany jako stosunek importu dóbr zaopatrzeniowych wykorzystywanych przez rząd do sumy wydatków publicznych $\left(m_{G}=g M_{D z} / G\right)$. Dalej obliczono współczynnik importochłonności inwestycji prywatnych $\left(m_{I P}\right)$. W poprzednim punkcie został on opisany jako $m_{I P}=M_{D I}+a p M_{D Z} / I P$. Omówione wcześniej zostały także współczynniki $p$ i $a$. Na koniec obliczono współczynnik importochłonności eksportu $\left(m_{X}\right)$. Został on określony jako stosunek części importu dóbr zaopatrzeniowych do wartości eksportu $\left(m_{X}=e p M_{D z} / X\right)$. Wyniki tych kalkulacji przedstawiono na wykresie 5 . Już ogólna analiza przedstawionych danych pozwala stwierdzić, że współczynnik importochłonności akumulacji brutto wykazuje się dość dużymi

Wykres 5

Wskaźniki importochłonności
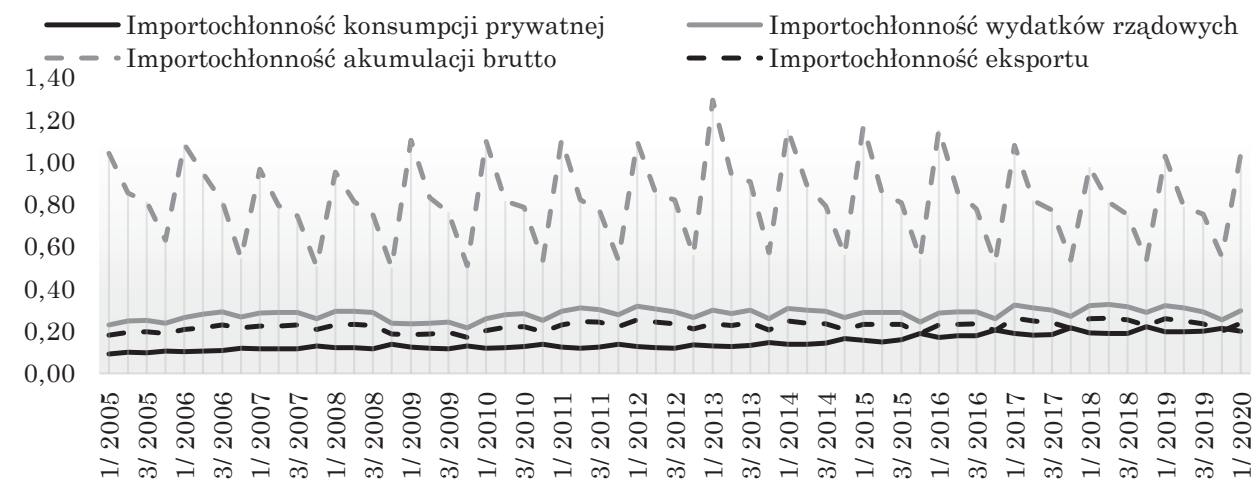

Źródło: opracowanie własne na podstawie ZBDE NBP.

skokami w ciagu roku. Współczynnik zmienności w analizowanym okresie wynosi $24,6 \%$. Na wykresie 6 przedstawiono natomiast przeciętne wartości współczynników importochłonności w układzie czterokwartalnym $\bar{m}(q n)$, gdzie $q_{n}$ oznacza badany okres czterech kwartałów. Przy czym $m\left(q_{n}\right)=\left[m\left(q_{0}\right)+m\left(q_{-1}\right)+m\left(q_{-2}\right)+m\left(q_{-3}\right)\right] / 4$. Oznacza to, że wartość przedstawiona na wykresie w kwartale $q_{n}$ jest średnią wartościa poszczególnych mnożników w tym kwartale oraz w trzech poprzednich (średnia ruchoma z czterech kwartałów). Tym sposobem uzyskano wykres znacznie wypłaszczony. Z dużym prawdopodobieństwem zmienność tę można wytłumaczyć zjawiskiem sezonowości. Wykorzystując dane kwartalne do takich analiz, należałoby dokonać także analizy w tym kontekście. Nie jest jednak celem autora w tym opracowaniu badanie samych wartości mnożników wydatków autonomicznych czy też poziomów importochłonności. Jest nim próba rewizji metody podziału importu, 
Wykres 6

Wskaźniki importochłonności - wartości średnie z 4 kwartałów

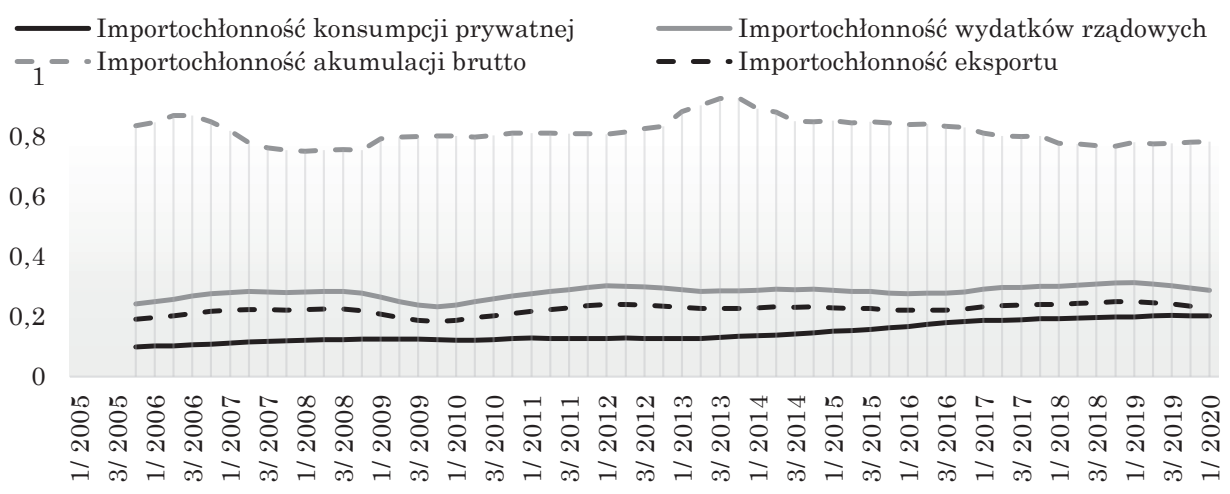

Źródło: opracowanie własne na podstawie ZBDE NBP.

która ma posłużyć do obliczania wartości mnożników fiskalnego, inwestycyjnego i eksportowego w krótkim czasie. Nie zmienia to jednak faktu, że poziom importochłonności akumulacji brutto jest najwyższy w polskiej gospodarce w stosunku do trzech pozostałych. Oznacza to, że działalność wpisana w akumulację brutto wykazuje się bardzo dużą absorpcją importu dóbr zaopatrzeniowych i inwestycyjnych.

W tym kontekście warto przeanalizować samą strukturę absorpcji importu przez poszczególne wydatki autonomiczne i konsumpcję prywatną (zob. wykres 7). Na tym zestawieniu widać bardzo wyraźnie, że wartość importu wykorzystywanego przez inwestycje prywatne w analizowanym okresie spada w sposób znaczący. Rośnie z kolei wartość importu przeznaczonego na konsumpcję prywatną oraz eksport. Już na tej podstawie można zaryzykować stwierdzenie, że w analizowanym okresie mamy do czynienia ze zmianą struktury ekonomicznej w polskiej gospodarce.

\section{Wykres 7}

\section{Struktura absorpcji importu}

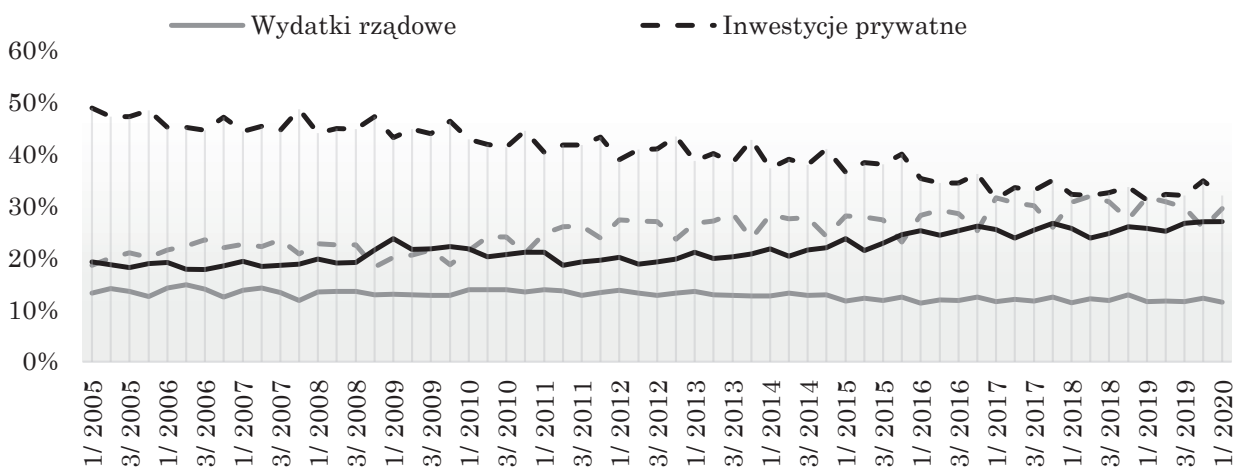

Źródło: opracowanie własne na podstawie ZBDE NBP. 
Na podstawie powyższych wyników można obliczyć teraz wartości mnożnika fiskalnego $\left(k_{1}\right)$, inwestycyjnego $\left(k_{2}\right)$ i eksportowego $\left(k_{3}\right)$. W tym celu posłużymy się wzorem (8). Obliczenia wykonano dla polskiej gospodarki, przyjmujac krótki okres (1 kwartał). Na wykresie 8 przedstawiono wyniki tych obliczeń. Analizując te dane, można zauważyć dość wyraźne trendy. Ponadto widać tu regularne wahania sezonowe. Znajduje to uzasadnienie w tym, że do badań przyjęto dane kwartalne. Ten fakt podpowiada, że w przyszłości warto poddać szczegółowej analizie zmiany mnożników wydatków autonomicznych z uwzględnieniem sezonowości. Na potrzeby tego opracowania niech wystarczy stwierdzenie, że współczynnik zmienności kwartalnej od 2005 r. wynosi, odpowiednio, dla mnożnika fiskalnego - 11,73\%, dla mnożnika inwestycyjnego - 113,73\%, a dla mnożnika eksportowego - 11,61\%.

Wykres 8

Mnożniki wydatków autonomicznych

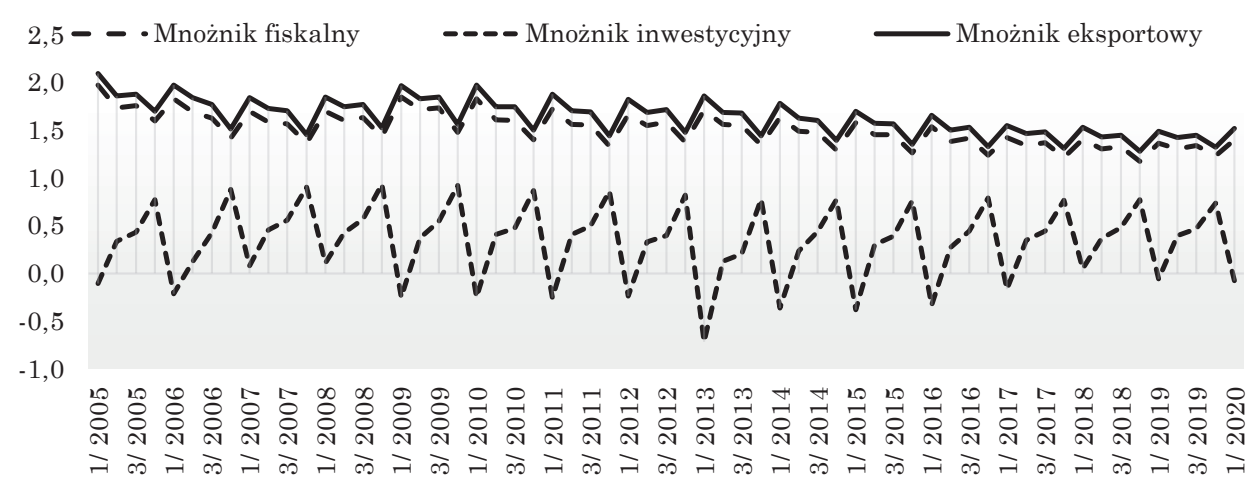

Źródło: opracowanie własne na podstawie ZBDE NBP.

Warto także zauważyć jeszcze jeden fakt. Mnożnik fiskalny w analizowanych okresie osiagnął wartość minimalną na poziomie 1,18, a wartość maksymalna na poziomie 1,97 . Mediana w tym okresie wynosi 1,54 . To sprawia, że wydatki rządowe sa znaczacym determinantem zmian PKB w polskiej gospodarce. Podobne wnioski można wyciagnąć z szybkiej analizy wartości mnożnika eksportowego. W tym przypadku minimalna wartość to 1,28 , a maksymalna 2,10. Mediana w tym okresie dla mnożnika eksportowego wynosi 1,66. Nieco inaczej wyglądają wartości mnożnika inwestycyjnego. W tym przypadku wartość minimalna wyniosła $-0,72$, a maksymalna 0,94. W tym miejscu warto krótko wspomnieć, iż ujemna wartość mnożnika ujawnia bardzo niska skuteczność, żeby nie powiedzieć nieefektywność, inwestycji w stosunku do PKB. W takiej sytuacji odnotowuje się niższy przyrost PKB niż wartość samej iniekcji, w tym przypadku inwestycji prywatnych. Jednocześnie należy zauważyć, że analizowane są tu wartości kwartalne. Ta sytuacja pozwala na stwierdzenie, że zastosowana tu metoda obliczania mnożników umożliwia 
dość szczegółową analizę tych zmiennych w gospodarce. Takiej możliwości nie było, gdy stosowano klasyczną metodę obliczania mnożników wydatków autonomicznych, bazująca na przepływach międzygałęziowych, które są publikowane co 5 lat. Mediana osiagnęła poziom 0,41. To sprawia, że wydatki związane z inwestycjami prywatnymi sa „mniej wartościowe” dla zmian PKB w Polsce. W tym kontekście wydaje się, że wartościowe byłoby obliczenie wartości poszczególnych mnożników, przyjmując dane roczne. To zagadnienie autor pozostawia jednak na kolejne badania.

\section{WNIOSKI}

Istotne znaczenie mnożników fiskalnego, inwestycyjnego i eksportowego polega na tym, że pokazują one reakcję PKB na zmiany poszczególnych wydatków autonomicznych. Tym samym mogą być one źródłem informacji o swoistej stabilności. Należy ją rozumieć w taki sposób, że sposób reagowania PKB jest względnie możliwy do przewidzenia, gdy znane są wartości wydatków autonomicznych. Zatem względna stabilność wartości mnożników może ułatwiać budowanie polityki gospodarczej kraju. Z kolei duża zmienność mnożników może powodować swoista niepewność w tym zakresie. Współczesne gospodarki sa otwartymi organizmami, w których globalna sieć dostaw jest czymś niemalże naturalnym. Im większa jest intensywność importu, tym poważniejszy staje się z nim (importem) problem. Można to było zaobserwować w czasie spowolnienia epidemiologicznego wywołanego wirusem COVID-19. Dlatego niezwykle istotne jest zastosowanie odpowiednich miar importochłonności $\mathrm{w}$ przewidywaniu wyników aktywnej polityki budżetowej i oszacowanie mnożników związanych $\mathrm{z}$ wydatkami publicznymi ${ }^{18}$, jak również wydatkami $\mathrm{w}$ zakresie inwestycji prywatnych i eksportu.

Głównym celem artykułu była próba rewizji metody szacowania współczynników importochłonności, a tym samym mnożników wydatków autonomicznych. W ramach podsumowania wydaje się, że najlepszym rozwiązaniem będzie przedstawienie i krótkie omówienie zmian wartości mnożnika fiskalnego, inwestycyjnego i eksportowego w Polsce, które zostały oszacowane według zaproponowanej metody. Taki obraz może być podstawą do dalszej dyskusji na temat wykorzystania zaproponowanego przez autora podziału importu w procesie kalkulowania wartości mnożników wydatków autonomicznych. Autor przedstawia te zmiany w formie graficznej. Przedstawione zostaną zmiany wartości poszczególnych mnożników $\left(k_{1}, k_{2}, k_{3}\right)$ w kolejnych kwartałach $\Delta k=k_{t+1}-k_{t}$.

Znaczenie dla gospodarki mnożników fiskalnego, inwestycyjnego i eksportowego bazuje bezpośrednio na wzorze (9). Wynika z niego, iż zmiana wartości PKB jest napędzana przez wzrost zasilających wydatków autonomicznych (wydatki publiczne, inwestycje prywatne i eksport). Z drugiej strony mamy

${ }^{18}$ Łaski (2019): 101. 
do czynienia z wyciekiem popytu w postaci prywatnych oszczędności brutto oraz importu uzależnionego od poziomu importochłonności. Oznacza to, że mnożnik fiskalny, inwestycyjny i eksportowy (zob. wzór 8) ujawniają istnienie wycieków łącznego popytu, które je ostatecznie determinują. Finalnie wycieki te osłabiają wartość wydatków autonomicznych oraz ich wpływ na zmianę PKB. Tym samym zwiększaja poziom niepewności w gospodarce. Na podstawie wzoru (5.3) można powiedzieć, że wzrost mnożniów $k$ powoduje przyspieszenie wzrostu wartości PKB. Jednak wzrost tego mnożnika jest uzależniony od poziomu importochłonności oraz od skłonności do konsumpcji prywatnej. Zależność wygląda następująco. Wzrost poziomu importochłonności powoduje zmniejszenie wartości mnożnika. Natomiast wzrost skłonności do konsumpcji wpływa pozytywnie na jego wartość. Oczywiście mówiąc o importochłonności, należy wybrać odpowiedni wskaźnik ze względu na analizowaną zmienną wydatków autonomicznych. W tym kontekście analizowane są zmiany mnożników fiskalnego, inwestycyjnego i eksportowego w polskiej gospodarce.

Przeanalizujmy zatem absolutne zmiany mnożników wydatków autonomicznych w układzie kwartał do kwartału roku poprzedniego. Na podstawie obliczeń przedstawionych w punkcie III dowiadujemy się, że współczynnik zmienności mnożników fiskalnego oraz eksportowego jest relatywnie wysoki, a mnożnika inwestycyjnego bardzo wysoki. Widać to także na wykresie 9. Znaczenie mnożników dla gospodarki, dla jej prognozowania oraz uprawiania polityki gospodarczej jest bezsprzecznie istotne. Przeprowadzone badania z wykorzystaniem zaproponowanej metody podziału importu pozwalają na analizę ich zmienności w krótkim okresie.

Wykres 9

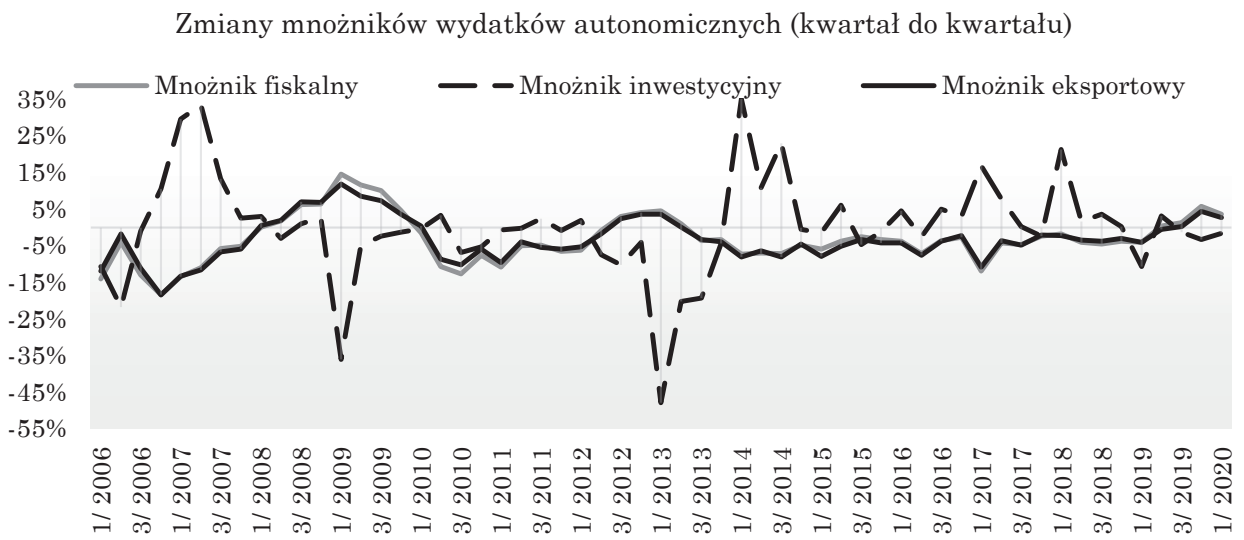

Źródło: opracowanie własne na podstawie ZBDE NBP.

Przyjrzyjmy się zatem wskaźnikom zmienności poszczególnych mnożników. Autor przeanalizował je w sposób dość szczegółowy. W tabeli 1 przedstawiono współczynniki zmienności mnożników fiskalnego, inwestycyjnego i eksportowego 


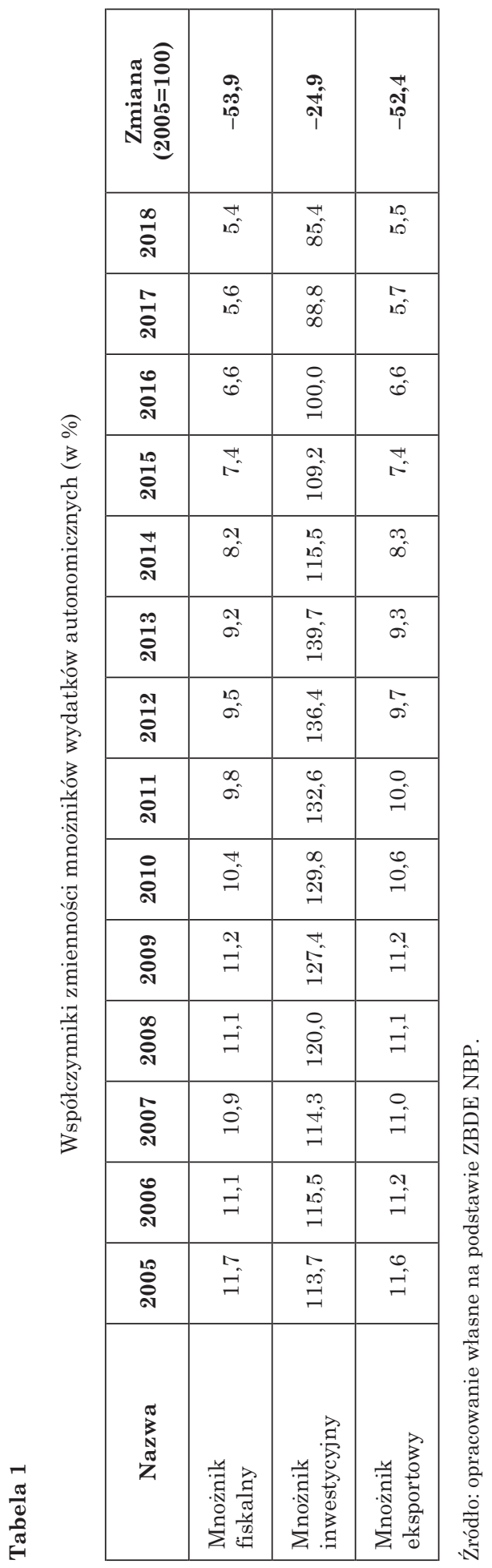


w okresie od I kwartału poszczególnych lat (od 2005 do 2018) do I kwartału roku 2020. Innymi słowy autor skracał o rok przedział czasu, w którym obliczał poszczególne współczynniki zmienności. Ostatnim, a jednocześnie najkrótszym analizowanym okresem zmienności wartości mnożników jest okres 2018-2020.

Analiza ta pozwala na wyciagnięcie pewnych wniosków. Widać, że poziom zmienności wartości mnożnika fiskalnego maleje od wartości 11,7\% (w okresie 2005-2020) do 5,4\% (w okresie 2018-2020). Oznacza to, że zmienność mnożnika fiskalnego spadła o 53,9\%. Można zatem powiedzieć, że wartość mnożnika fiskalnego w badanym okresie dość wyraźnie się stabilizuje. Jest to widoczne także na wykresie 8. Inaczej wygląda sytuacja zmienności mnożnika inwestycyjnego. $\mathrm{W}$ analizowanym okresie zmienność ta jest bardzo wysoka. Dopiero w okresie od 2017 r. współczynnik zmienność kwartalnej spadł poniżej 100\%. Najsilniejsze zmiany mnożnika inwestycyjnego odnotowano w okresie 2013-2020, kiedy to współczynnik zmienności osiagnął wartość $139,7 \%$. W całym analizowanym okresie zmienność wartości mnożnika fiskalnego spadła o 24,9\%. Charakterystyczne jest to, iż zmienność tego mnożnika jest znacząco wyższa od dwóch pozostałych. Możemy więc stwierdzić, że reakcja PKB na zmianę inwestycji prywatnych jest dość niestabilna w krótkich okresach kwartalnych. Pozostaje jeszcze krótkie omówienie współczynników zmienności mnożnika eksportowego. $\mathrm{Na}$ podstawie danych przedstawionych w tabeli 1 można powiedzieć, iż mnożnik ten charakteryzuje się bardzo podobną zmiennościa, którą widzimy dla mnożnika fiskalnego. Całkowita zmiana współczynnika zmienności w analizowanym okresie wyniosła $-52,4 \%$. Przy czym maksymalna wartość tego współczynnika osiąnęła poziom $11,6 \%$, a minimalna $5,52 \%$.

Przedstawione w artykule obliczenia i analizy w głównej mierze bazują na teorii efektywnego popytu. Autor zaproponował nowatorskie podejście do podziału importu, co umożliwiło dokonanie szczegółowej analizy mnożników fiskalnego, inwestycyjnego i eksportowego w krótkim okresie. Przyjęta metoda pozwoliła na zbadanie zmienności wartości poszczególnych mnożników wydatków autonomicznych. Tym samym stała się ona - jak się wydaje - narzędziem do badania reakcji PKB na zmiany wydatków autonomicznych w krótkim okresie. Przedstawione wyliczenia opisujące polska gospodarkę w okresie od 2005 do 2020 roku pokazały wartość tejże metody. Pozostaje mieć nadzieję, że ten sposób obliczania mnożników fiskalnego, inwestycyjnego i eksportowego znajdzie uznanie $\mathrm{w}$ środowisku ekonomistów. $\mathrm{Z}$ cała pewnością otwiera ona nowe możliwości na badania ekonomiczne w zakresie determinantów zmian wartości produktu krajowego brutto.

Abdi, H. (2010). Coefficient of variation, [w:] Encyclopedia of Research Design 1: 169-171.

Akerlof, G.A., Yellen, J.L. (1987). Rational models of irrational behavior. The American Economic Review 77(2): 137-142.

Andrade, E., Mattos, F., Souza Lima, R.A. de (2018). New insights on hedge ratios in the presence of stochastic transaction costs. Risks 6(4), 118. doi:10.3390/risks6040118 
Czyżewski, A., Kryszak, L. (2016). Współzależności międzygałęziowe w sektorze rolnym w świetle modelu input-output a poziom finansowego wsparcia rolnictwa w wybranych krajach. Problemy Rolnictwa Światowego 16(2): 55-65.

Fischer, P. (2011). Selective exposure, decision uncertainty, and cognitive economy: a new theoretical perspective on confirmatory information search. Social and Personality Psychology Compass 5(10): 751-762.

Ko, Ch.-Ch., Lin, T.T., Zeng, F.-M., Liu, Ch.-Y. (2018). Optimum technology product life cycle technology innovation investment-using compound binomial options. Risks 6(3), 98. doi:10.3390/ risks6030098

Łaski, K. (2019). Lectures in Macroeconomics: A Capitalist Economy Without Unemployment.

Łaski, K., Osiatyński, J., Zięba, J. (2010a). Czynniki wzrostu PKB w Polsce i w Czechach w 2009 r. Ekonomista 6: 805-830.

Łaski, K., Osiatyński, J., Zięba, J. (2010b). The government expenditure multiplier and its estimates for Poland in 2006-2009. Working Paper of Vienna Institute for International Economic Studies 63: 1-14.

Łaski, K., Osiatyński, J., Zięba, J. (2010c). Mnożnik wydatków państwowych i szacunki jego wielkości dla Polski. Narodowy Bank Polski. Departament Edukacji i Wydawnictw.

Łaski, K., Osiatyński, J., Zięba, J. (2012). Fiscal multipliers and factors of growth in Poland and the Czech Republic in 2009. National Bank of Poland Working Paper 117: 1-26.

Palley, Th.I. (2009). Imports and the income-expenditure model: implications for fiscal policy and recession fighting. Journal of Post Keynesian Economics 32(2): 311-322.

Przybyliński, M. (2012). Metody i tablice przepływów międzygałęziowych w analizach handlu zagranicznego Polski. Łódź.

Rueda-Cantuche, J.M., Amores, A.M., Beutel, J., Remond-Tiederez, I. (2017). Assessment of European use tables at basic prices and valuation matrices in the absence of official data. Economic Systems Research 30(2): 252-270.

Schultz, Ch. (2002). Policy biases with voters' uncertainty about the economy and the government. European Economic Review 46(3): 487-506.

\section{ESTIMATES OF FISCAL, INVESTMENT AND EXPORT MULTIPLIERS IN THE POLISH ECONOMY IN 2005-2020}

\section{Sum mary}

The mechanism of autonomous expenditure multipliers in modern economics is one of the most important issues. The reason for this is that it reveals how much GDP changes as a result of changes in autonomous expenditure. In this context, the main purpose of the work is to attempt to verify the method of estimating fiscal, investment and export multipliers. In addition, the author attempted to estimate the autonomous expenditure multipliers for the Polish economy in the period 2005-2020. To achieve the goal, the author uses a classic methodology based on the theory of total demand. In addition, the basic assumptions of the Keynesian economic model were adopted. The main inspiration for this work is the frequent claim that it is difficult to estimate the levels of import intensity in accordance with the adopted concept of total demand. That is why the author attempted to present a new concept of import distribution. This allowed the calculation of autonomous expenditure multipliers in the short term. Based on the described method, the author made detailed estimates of fiscal, investment and export multipliers for Poland in the analysed period.

Keywords: zasada efektywnego popytu; fiscal multiplier; investment multiplier; export multiplier; JEL Codes: E0, E12, E20, E63 
